\title{
Response of Bread Wheat (Triticum aestivum L.) to Different Blended Fertilizer Application A-Review
}

\author{
Mr. Demisew Amare (MSc)* \\ Collage of Agriculture and Natural resources, Department of plant Sciences, \\ Bonga University P.O. Box 334, Bonga, Ethiopia
}

\begin{abstract}
Wheat is the most important and widely cultivated crop of the entire world. It is principal food of human beings and Ethiopia is one of the important wheat producing countries in world. Wheat responds well to fertilizer application with balance nutrients for increased wheat productivity. Fertilizer is the most important input, which contributes significantly towards final grain yield of wheat and to exploit the inherited potential of cultivar, but productivity wheat for long time was low due to the absence of essential/unbalanced crop nutrition. To overcome this problem Ministry of Agriculture and Natural resource introduced different blended fertilizer according to soil test in different parts of the country. Recently farmers in most part of country are using this newly introduced blended fertilizers like NPS, NPSB, NPSBZn, which was replaced by, DAP, are most essential nutrient containing fertilizer which used for plant growth quality, yield as well as plays a fundamental role in metabolism and energy producing reaction. These blended fertilizers are currently fulfilling farmers/ producers demands by increasing their production and productivity as shown by different researchers. This review was mainly focused on the response of wheat to different blended fertilizers.
\end{abstract}

Keywords: Blended, Fertilizer

DOI: $10.7176 / \mathrm{JBAH} / 10-5-03$

Publication date:March $31^{\text {st }} 2020$

\section{INTRODUCTION}

Wheat (Triticum spp.) is one of the major cereal crops grown in the highlands of Ethiopia and this region is regarded as the largest wheat producer in Sub-Saharan Africa (Eprem et al., 2000). In Ethiopia wheat has become one of the most important cereal crops ranking fourth both in total grain production (4.54 million tons) and area coverage (1.69 million hectare) next to teff, maize and sorghum (CSA, 2017). Though Ethiopian agro-climatic condition is suitable for wheat production, the productivity is low (2.67t ha-1) (CSA, 2017). This is because of depleted soil fertility, low levels of chemical fertilizer usage, limited knowledge on time and rate of fertilizer application, and the unavailability of other modern crop management inputs (Anderson and Schneider, 2010). As summarized by Tekalign et al. (2001), nitrogen $(\mathrm{N})$ is deficient in almost all soils and phosphorus $(\mathrm{P})$ is deficient in about $70 \%$ of the soils in Ethiopia. This low nutrient content is due to erosion and absence of nutrient recycling. Plants require a variety of elements for the growth and development of which N, P, K, S, Zn and, B are the most important of the essential nutrients to plants because they are required in large quantities for wheat productivity of bread wheat (Abebual et al., 2019). The application of appropriate application of fertilizer one of the agronomic practices that increase productivity wheat (Brady and Weil, 2002).

In Ethiopia, crop production has been focused mainly on the use and application of nitrogen and phosphorous fertilizers in the form of Di-ammonium phosphate (DAP) (18-46-0) and Urea (46-0-0) or blanket recommendation for the major food crops. Continuous application of nitrogen $(\mathrm{N})$ and phosphorus $(\mathrm{P})$ fertilizers without consideration of other nutrients led to the depletion of other important nutrient elements such as potassium $(\mathrm{K})$, magnesium (Mg), calcium (Ca), sulfur (S) and micronutrients in soils (Abiye et al., 2004). Balanced fertilization is the key to sustainable crop production and maintenance of soil health. It has both economic and environmental consideration. An imbalanced fertilizer use results in low fertilizer use efficiency leading to less economic returns and a greater threat to the environment (Abiye et al., 2004).

Moreover, recently acquired soil inventory data revealed that the deficiencies of most of nutrients such as, nitrogen $(86 \%)$, phosphorus $(99 \%)$, sulfur $(92 \%)$, born $(65 \%)$ and zinc $(53 \%)$ are widespread in Ethiopian soils (Ethio-SIS, 2013). By considering this, many researchers are conducting research on improving crop productivity of wheat through application of different blended fertilizer. Dagne (2016) observed that the maximum mean grain yield (8399.7 kg ha-1), stover yield (8553.1 kg ha-1) and total biomass yield (16867.7 kg ha-1) were recorded from blended fertilizers, whereas the lowest were recorded for the control in maize.

The responses of blended fertilizer on wheat were conducted on two varieties Wane and Kingbird. The numbers of productive tillers per plant were significantly affected by the interaction effect of varieties and fertilizer rates. The result showed that the maximum number of productive tiller (7.7) and (6) were recorded from $300 \mathrm{~kg}$ NPSB $+100 \mathrm{~kg}$ Urea ha Wane and Kingbird varieties respectively. The highest result of Wane and Kingbird verities were improved by $42.9 \%$ and $26.7 \%$ respectively as compared to the lowest number of productive tillers per plant at control (Rut-Duga et al., 2019). Abebaw and Hirpa, (2018) reported that blended fertilizer and sowing 
method significantly affect plant height. When averaged over treatments, the highest mean height $75.8 \mathrm{~cm}$ was recorded from of $150 \mathrm{~kg}$ blended NPSZB fertilizer / ha with row sowing, while lowest mean plant height was observed from treatments that receive $0 \mathrm{~kg}$ fertilizer (control) with broad casting and $100 \mathrm{~kg}$ DAP $+100 \mathrm{~kg}$ of urea / ha as 47.46 and $55.67 \mathrm{~cm}$, respectively. The plant height of plots that received $150 \mathrm{~kg}$ blended fertilizer / ha under row planting indicated a height increase by $37.38 \%$ compared to $0 \mathrm{~kg}$ fertilizer under broad cast planting (control) and $26.55 \%$ to $100 \mathrm{~kg}$ DAP $+100 \mathrm{~kg}$ urea. This paper was, therefore carried out with objective to review effect of different blended fertilizer on yield and yield components of bread wheat.

\section{The Role of Fertilizers in Crop Production}

Fertilizer usage plays a major role in the universal need to increase food production to meet the demands of the growing world population. Fertilizer application resulted in marked crop yield increases, which for most crops was more than hundred percent (Mengel and Kirkby, 1996). The extent to which fertilizers are used still differs considerably between various regions of the world (Mengel and Kirkby; 1996). The quantity of fertilizer nutrients required for optimum crop production depends on the inherent capacity of the soil to supply adequate levels of nutrients to growing plants the yield potential of the crop variety grown (Tilahun et al; 1996) and the availability and cost of fertilizers and climatic conditions prevailing during the crop-growing season (Baligar and Bennett; 1986).

Plants require nutrients in balanced amounts depending on their stage of development and yield levels. For optimal nutrition of crops, a sufficient concentration of the individual nutrients should be present in the plant leaves at any time. For fast-growing crops and high yields, the daily nutrient supply must be adequate, especially during the period of maximum requirement. It is clear that both $\mathrm{N}$ and $\mathrm{P}$ are essential elements in their structural, biochemical and physiological roles contributing to crop growth. Furthermore, the dependence of crop growth on $\mathrm{N}$ and $\mathrm{P}$ is a quantitative one. Virtually all of the compounds that participate in metabolism, cell growth and tissue development contain $\mathrm{N}$ and/or $\mathrm{P}$. Therefore, diminished levels of $\mathrm{N}$ and $\mathrm{P}$ have many ramifications that result in quantitative decreases in the rate of growth, and ultimately yield. Commonly, decreases in either $\mathrm{N}$ or $\mathrm{P}$, which is likely under low-nutrient conditions, leads directly to decreases in the levels of the critical compounds required to sustain high rates of growth. It should be no surprise, therefore, that there is frequently a close correlation between crop yield and the amount of $\mathrm{N}$ and $\mathrm{P}$ that the plants have accumulated (MoANR 2010).

The quantity of fertilizer nutrients required for optimum crop production depends on the inherent capacity of the soil to supply adequate levels of nutrients to growing plants, the yield potential of the crop variety grown (Tilahun et al; 1996) and the availability and cost of fertilizers and climatic conditions prevailing during the cropgrowing season. Due to the recent release of improved high yielding bread wheat varieties adapted to heterogeneous environmental conditions in Ethiopia, wheat grain yield potential has significantly increased and area coverage has substantially expanded (Hailu; 1991). Recently released cultivars are highly responsive to improved crop management systems and require higher rates of nutrients' applications. One of the basic limiting factors for wheat yields on highland plateau of Ethiopia is poor soil fertility, especially the deficiency of the two macronutrients, nitrogen and phosphorus (Asnakew et al., 1991).

\section{Effect of Different Blended Fertilizer on Growth and Yield of Wheat Days to $50 \%$ heading and $90 \%$ physiological maturity}

Appropriate supply of the nutrients like N, P K, S, and B and ZN are currently essential for growth and development of wheat crop. Abebual et al, 2019) reported that increasing blended fertilizer, N.P, S, ZN and B, significantly increase plant growth and development of wheat. As indicated, that indicated that the combination of NP fertilizer with K, S, Zn and B, enhanced the early heading of wheat. However Abebaw and Hirpo (2018) stated that that application of blend fertilizer (macro and micro) and urea, having higher rate of nitrogen nutrient prolongs vegetative growth stage of wheat, but the control treatment $0 \mathrm{~kg}$ fertilizer and $100 \mathrm{~kg}$ DAP and $100 \mathrm{~kg}$ UREA showed shortest days which could be nutrient deficiency fastens to develop spike for wheat.

Diriba, Shiferaw G, et al., (2019) reported that, blended fertilizer significantly affected days to heading and maturity. The longest days to heading (71.7) and physiological maturity (113.0) was observed at $300 \mathrm{Kg}$ of NPSB application with supplementary urea. The shortest dates of heading and physiological maturity were observed for both varieties (61.3) and (106.2) at control, respectively. This difference could be attributed to the application different rates of blended fertilizer rates for bread wheat varieties. However, Tilahun and Tamado, (2018 showed that days to $50 \%$ heading and days to $90 \%$ physiological maturity were not significantly affected by of blended NPS fertilizer rates. Similarly Tegesa et al., (2018) stated that application of blended did not have significant effect on days to heading, but days to physiological maturity was highly significantly affected by blended NPS fertilizer on bread wheat. Abebual et al., (2019) reported that days to $50 \%$ heading and days to $90 \%$ physiological maturity significantly $(\mathrm{P}<0.01)$ affected by blended fertilizer application as compared to control treatment. Application blended fertilizer formulations resulted reduced the days to $50 \%$ heading by 11 days and significantly reduced days to attain maturity than the control treatment. as concluded that the combination of NP fertilizer with K, S, 
$\mathrm{Zn}$ and $\mathrm{B}$, enhanced the early heading and brought earliness in days to $90 \%$ physiological maturity than unfertilized plot wheat. Tagesa et al., (2018) reported that application of Blended NPS fertilizer did not influenced days to heading but days to $90 \%$ physiological maturity significantly influenced by application of blended fertilizer.

\section{Plant height}

Abebual et al (2019) showed that there were significant variations $(\mathrm{P}<0.001)$ among the fertilizers types on wheat height. Application of blended fertilizer significantly increased plant height as compared to the control. Similarly, the recommended NP fertilizers also significantly increased plant height as compared to the control. However, supplementation of S, B and $\mathrm{Zn}$ to the recommended NP fertilizers did not bring about a significant difference in plant height. The increment in plant height might be due to increase in cell elongation and more vegetative growth attributed to different nutrient content of blended fertilizer containing NPS and micronutrients. additionally Sulphur is one of the essential nutrients for plant growth and it accumulates 0.2 to $0.5 \%$ in plant tissue on dry matter basis. It is required in a similar amount as that of phosphorus (Ali et al., 2008). It is also building block of protein and a key ingredient in the formation of chlorophyll (Duke and Reisenaue, 1986). Tazeh et al. (2012) stated that application of compost and sulphur might reduce soil $\mathrm{pH}$, increase phosphorous, and some micronutrient availability in soil. The increasing of sulfur content up to $100 \mathrm{~kg} \mathrm{ha}^{-1}$ caused a significant increase in wheat root and shoot growth as well as nutrient uptake. Without adequate $\mathrm{S}$, crops cannot reach their full potential in terms of yield or protein content (Zhang et al., 1999). It is required for the synthesis of $\mathrm{S}$ containing amino acids such as, cysteine and methionine. Their deficiency results in stunted growth, reduced plant height, tillers, spikelets and delayed maturity. Sulfur deficient plants have also less resistance under stress conditions (Doberman and Fairhurst, 2000).

On the other hand, the least plant height in unfertilized plots might have been due to low soil fertility level that result low height in plants, plant growth and development may be retarded significantly if any of nutrient elements is less than its threshold value in the soil or not adequately balanced with other nutrient elements (Landon, 2014).

Abebaw and Hirpa, (2018) reported that blended fertilizer and sowing method significantly affect plant height. When averaged over treatments, the highest mean height $75.8 \mathrm{~cm}$ was recorded from of $150 \mathrm{~kg}$ blended NPSZB fertilizer / ha with row sowing, while lowest mean plant height was observed from treatments that receive $0 \mathrm{~kg}$ fertilizer (control) with broad casting and $100 \mathrm{~kg}$ DAP $+100 \mathrm{~kg}$ of urea / ha as 47.46 and $55.67 \mathrm{~cm}$, respectively. The plant height of plots that received $150 \mathrm{~kg}$ blended fertilizer / ha under row planting indicated a height increase by $37.38 \%$ compared to $0 \mathrm{~kg}$ fertilizer under broad cast planting (control) and $26.55 \%$ to $100 \mathrm{~kg}$ DAP $+100 \mathrm{~kg}$ urea. Similarly, Tegesa, et al (2018) reported that significant effect of blended fertilizer on plant height, in which application of blended NPS fertilizer, 100, 150, and $200 \mathrm{~kg}$ /ha produce mean value 74.8, 83.6, and $81.07 \mathrm{~cm}$ on plant height respectively. This is due to the Phosphorus $(\mathrm{P})$ is the second key plant nutrient required in large quantities for growth and productivity of crops. It has a role in cell division, stimulation of early root growth, hastening plant maturity and energy transformation within the cell and in fruiting and seed production. Because it is a constituent element of nucleoproteins, which are involved in the cell reproduction processes (Miller and Donahue, 1997).

Tilahun and Tamado, (2018 showed main effects of blended NPS significantly affect plant height. Increasing the amount of NPS, rates significantly increased plant height. The maximum application rate of blended NPS (200 $\mathrm{kg}$ ha-1) $\mathrm{r}$ resulted in the highest plant height $(79.59 \mathrm{~cm})$ while application of application of 100kg NPS blended fertilizer produce $77.53 \mathrm{~cm}$. The increased plant height in response to increasing rate of NPS blended fertilizer was due to nitrogen effect on the Blended fertilizer, which has the vital role of $\mathrm{N}$ fertilizer in promoting the vegetative growth, and resulted in significant increase in plant height.

Diriba, et al., (2019) reported that, application of blended fertilizer(NPSB significantly affected plant height of bread wheat, as indicated that increasing of blended fertilizer increased plant height in which the highest $(95.5 \mathrm{~cm})$ plant height was observed due to the application of the 300NPSB fertilizer rate as compared with control treatment which was $75.6 \mathrm{~cm}$.

\section{Effect different blended fertilizer on yield components and yield}

Abebual et al (2019) studied that the application of blended fertilizers significantly influenced number of total and effective tiller per plant. Application of blended fertilizer significantly increased number of total and effective tiller per plant as compared to the control. The minimum number of total and effective tillers per plant was recorded at control. Diriba, et al., (2019) reported that Number of productive tillers per plant was significantly influenced by the interaction effect of varieties and fertilizer rates. The response of the crop in terms of number of effective tillers in Wane (7.7) and Kingbird (6.0) varieties were higher at $300 \mathrm{Kg}$ of NPSB application. Wane variety at $200 \mathrm{~kg}$ NPSB (7.0), $250 \mathrm{~kg}$ NPSB (7.3) and $300 \mathrm{~kg}$ NPSB (7.7) fertilizer rates applications was statistically non-significant. The lowest numbers of effective tillers (4.4) were recorded for both varieties at control plot; which might be due to the role of $\mathrm{N}$ in accelerating vegetative growth of plants. Similarly Baraich et al. (2012) conducted that 
application of $90 \mathrm{~kg} \mathrm{ha}^{-1} \mathrm{P}$ fertilizer resulted in maximum values for plant height $(84.05 \mathrm{~cm})$, number of tillers (6.36 plant $\left.^{-1}\right)$, spike length $(10.85 \mathrm{~cm})$, number of grains $\left(66.33\right.$ spike $\left.^{-1}\right)$, seed weight $(48.38 \mathrm{~g})$ and grain yield (4504.33 kg ha-1). While analyzing the increase percent in growth and grain yield components in treated plots over control, it was observed that $90 \mathrm{~kg} \mathrm{P} \mathrm{ha}^{-1}$ treatment resulted in an increase of $103.11 \%$ in plant height, $97.51 \%$ in tillers plant ${ }^{-1}, 90.01 \%$ in spike length, $84.04 \%$ in number of grains spike- $1,92.82 \%$ in seed index and $115.89 \%$ in grain yield ha ${ }^{-1}$ over control. Damene (2003) reported that an increase in the number of spikes was significantly higher due to the application of $40 \mathrm{~kg} \mathrm{P}^{-1}$ than that recorded the application of 20 and $10 \mathrm{~kg} \mathrm{P} \mathrm{ha}^{-1}$ and the control, while no significant differences were observed between 30 and $40 \mathrm{~kg} \mathrm{P} \mathrm{ha-1}$. Kaleem et al., (2009) who recorded maximum yield of $3557 \mathrm{~kg} \mathrm{ha}^{-1}$ by the application of $128-128 \mathrm{~kg}$ ha-1 (NP) ratio $1: 1$ which was indicating importance of phosphorus at its highest dose in achieving maximum wheat productivity.

Tegesa, et al (2018) reported that significant effect of blended NPS fertilizer on both total and productive number of tillers of bread wheat, as reported that application of blended fertilizer increases total productive tillers per plant. Frehiwot (2014) also reported that $\mathrm{N}$ and $\mathrm{P}$ fertilizer had potential role in number of total and effective tiller production per plant. On other hand, Hailu, (2014) showed that applications of blended fertilizers (NPS $+\mathrm{ZnB})$ were on parity with the blanket recommendation of DAP and Urea fertilizers and gave significantly higher number of total and effective tillers of wheat. However, Tilahun and Tamado, (2019) also showed that application of the blended NPS fertilizer had not shown significant difference on tillers of wheat.

Field experiment conducted at Tiyo district in Eastern Arsi, Ethiopia on farmer's field showed that grain yield, aboveground dry biomass and numbers of productive tillers were significantly affected by the interaction effect of varieties and fertilizer rates. The highest seeds per spike (53.9), thousand-kernel weight (37.3 g), and straw yield (9071.7 kg ha-1) were recorded from $300 \mathrm{~kg}$ NPSB ha-1 application along supplementary urea. Higher grain yield was harvested from Wane (4236 kg ha-1) variety at $300 \mathrm{~kg}$ NPSB ha-1 fertilizer rate (Diriba, et al., 2019).

Field experiment was conducted during 2017 cropping season in Siyadebrenawayu district, central Ethiopia with the objective to evaluate the effect of different blended fertilizer formulation of S, B, Zn and K on yield and yield components of bread wheat found that yield and yield components of bread wheat was significantly affected by the treatments except 1000-grain weight. The highest above ground dry biomass yield (14.29 tha-1), highest grain yield (5.77 tha-1) and straw yield (8.51 tha-1) was recorded from additional application of $\mathrm{S}, \mathrm{B}$, and $\mathrm{Zn}$ $(11.1 \mathrm{~S}, 0.15 \mathrm{~B}, 3.3 \mathrm{Zn}) \mathrm{kgha}-1$, ) kgha-1. The application of blended fertilizer $175 \mathrm{NP} 11.1 \mathrm{~S}, 0.15 \mathrm{~B}, 3.3 \mathrm{Zn}$ increased the straw and grain yield by $35.45 \%$ and $19 \%$ respectively as compared to the recommended NP fertilizer( $175 \mathrm{~kg}$ ha-1 (Abebual etal,.2019).

Field experiment was carried out on farmer's field at Arsi Negelle, Central Ethiopia reveal that, that interaction effect of blended NPS and supplemented N significantly $(\mathrm{p}<0.05)$ influenced number of total tillers and total productive tillers per $\mathrm{m}^{2}$ where, highest total tillers (343.3) and productive tillers (306.7) per $\mathrm{m} 2$ were recorded at the combination of $150 \mathrm{~kg}$ NPS ha-1 and $92 \mathrm{~kg} \mathrm{~N}$ ha-1. Similarly, main effect of blended NPS was significantly $(p<0.05)$ influenced grain yield where maximum grain yields $(5274 \mathrm{~kg}$ ha-1) at the highest application of 200 NPS kg ha-1 (Tilahun and Tamado, (2018).

Abebaw and Hirpa, (2018) studied revealed that yield and yield contributing characters were influenced significantly by different rate of blended fertilizer and sowing methods. The maximum number of effective tillers plant-1 (7.66), the highest grain yield (29.583 qt ha-1) and the highest straw yield (6.10 qt ha -1) were obtained from $200 \mathrm{~kg}$ blended NPSZnB fertilizer $+63.91 \mathrm{~kg}$ of urea. In contrast, the shortest plant $(52.11 \mathrm{~cm}$ and $59.55 \mathrm{~cm})$, the lowest number of effective tillers plant-1 (1.5 and 5.33), minimum grain yield (12.125 qt ha -1 and $18.194 \mathrm{qt}$ ha -1 and straw yield (37.78 qt ha -1 ) were observed when $0 \mathrm{~kg}$ fertilizer and $100 \mathrm{~kg}$ of DAP $+100 \mathrm{~kg}$ of urea applied. Study conducted at Debub-Ari woreda, South Ethiopia, showed that the significant effects of fertilizers were observed on wheat yield and yield components. The application of $200 \mathrm{~kg}(14 \mathrm{~N}-21 \mathrm{P} 2 \mathrm{O} 5-6.5 \mathrm{~S}-1.2 \mathrm{Zn}-0.5 \mathrm{~B})$ per ha and the remaining nitrogen (41 kg urea /ha-1 ) top dressed, resulted 36.8 and $57 \%$ grain yield and harvest index improvement (Tsegaye etal., 2018).

Similarly the study conducted at Angecha testing site of Areka Agricultural Research center, southern Ethiopia stated that importance application of on yield of wheat NPSCu (combination of Cu with macronutrients NPS) fertilizers in improving yield of wheat. In which the highest grain yield (4500 kg ha-1) and biomass (12.17 t ha-1) was obtained by application of NPSCu@ a rate of 69 N, 72 P2O5, 13 S kg ha-1) + 600 gm although not significantly differ from other rates of NPS and NPSCu except NPS @ lowest (46/54/10) rate. Inclusion of Cu on the NPS blend improved wheat production at Angecha and increased grain yield by only $12.8 \%$. Application of $69,72,13 \mathrm{~kg}$ ha-1+ $600 \mathrm{gm} \mathrm{Cu}$ ha-1 (NPSCu) increase wheat yield by 7\% over 69,72,13 kg ha-1 NPS (Yehuala and Tsadiku,2019).

\section{Conclusion}

In Ethiopia nutrient deficiency especially in addition to NPK, luck of other micro and macro element causing low production and productivity of different crops in different parts of the country. However, currently in the Ministry 
of Agriculture of Ethiopia has been recently introduced a new compound fertilizer like the one NPS, NPSB, NPSBZn, and NPSBZnCu containing are introduced to overcome this nutrient insufficiency. More over as many researcher concluded that the production and productivity of wheat crop was increase due to the application of appropriately soil recommended blended fertilizers across in different regions of the country. Therefore, application of soil test based blended fertilizer could be best means to boost production and productivity of wheat in Ethiopia.

\section{Reference}

Abebaw Tadele and Hirpa legese (2018).Effects of Fertilizer Rate (Blended) and Sowing Methods On Yield And Yield Components Of Bread Wheat (Triticum Aestivum) In Western Ethiopia ,Int. J. Compr. Res. Biol. Sci.(2018).5(6):1-16

Abebaw Tadele, and Hirpa Legese, (2018). Effects of fertilizer rate (blended) and sowing methods on yield of bread wheat (Triticum aestivum) and its economic profitability in Western Ethiopia. Journal of Comprehensive Research in Biological Sciences 5(7):1-14.

Abebual Woldetsadik, Wondwosen Tena and Asmare Melese, (2019). Effect of Different Blended Fertilizer Formulation on Yield and Yield Components of Bread Wheat (Triticum aestivum L.) in Siyadebrenawayu District, North Shewa, Ethiopia. Journal of Biology, Agriculture and Healthcare 9 (15): 13-23.

Asnakew Woldeab, Tarekegn Mammo, Mengesha Bekele and Tefera Ajema,( 1991). Soil fertility management studies and wheat in Ethiopia. pp 112-144. In: Hailu Gebre-Mariam, Tanner and Mengistu Hulluka (eds.). Wheat Research in Ethiopia. A Historical Perspective. IAR, CIMMYT, Addis Ababa, Ethiopia

Baligar, and Bennelt; (1986). Outlook on fertilizer use efficiency in the tropics. Fertilizer Research 10: 83-96

Baraich, A.A.K., Baraich, A.H.K., Jamali, L.A. and Salarzi, A.U., 2012. Effect of nitrogen application rates on growth and yield of cotton varieties. Pakistan Journal of Agriculture, Agricultural Engineering and Veterinary Sciences, 28, pp.115-123.

CSA (Central Statistical Authority). 2017. Agricultural sample survey 2016/17. Volume I. Report on area and production of major crops for private peasant holdings, meher season. Statistical bulletin 584. Central Statistical Agency, Addis Ababa, Ethiopia

Damene Darota. 2003. Yield Response of Bread Wheat (Triticum aestivum L.) to Applied Levels of N and P Fertilizers on Nitisol of Dawro Zone, Southwestern Ethiopia. MSc. Thesis. Haramaya University, Haramaya Ethiopia

Doberman, A. and Fairhurst, T., 2000. Nutriments Disorders and Nutriments Management. International Plant Nutrition Institute.

Duke, S.H. and Reisenauer, H.M., 1986. Roles and requirements of sulfur in plant nutrition. Sulfur in agriculture, 27, pp.123-168.

EthioSIS (Ethiopian Soils Information System). 2013. Status of soil resources in Ethiopia and priorities for sustainable management, GSP for eastern and southern Africa Mar 25-27 Nairobi, Kenya FAO (Food and Agriculture Organization of the United Nations).1984. Ethiopian highlands reclamation study (EHRS). Final Report, Vols. 1-2, Rome.

Hailu Gebre-Mariam; (1991). Wheat production and research in Ethiopia PP 1-5. In: Hailu Gebre Mariam, D. G. Tanner and Mengistu Huluka (eds.) wheat Research in Ethiopia: A Historical Perspective. IAR/CIMMYT, Addis Ababa.

Kaleem S., Ansarm.,Ali M., Sher A. and Rashid M. 2009. Effect of Phosphorus on the Yield and Yield Components of Wheat Variety Inqlab-91 Under Rainfed Conditions Sarhad Journal of Agriculture, 25(1):1989-1992.

Landon, J.R., 2014. Booker tropical soil manual: a handbook for soil survey and agricultural land evaluation in the tropics and subtropics. Routledge.

Mengel and Kirkby (1996). Principles of Plant Nutrition, Panimo Publishing Corporation, New Delhi, India.

MoA (Ministry Of Agriculture ).2010. Animal and Plant Health Regulatory Directorate. Crop Variety register, Issue No. 13. Addis Ababa, Ethiopia. Ministry Of Agriculture.

Rut-Duga D, Diriba-Shiferaw G, and Wogayehu Worku, 2019. Effects of Blended Fertilizer Rates on Bread Wheat (Triticum aestivum L.) Varieties on Growth and Yield Attributes. Journal of Biology, Agriculture and Healthcare Vol. 9 (15): 1-12.

Tagesse Abera, Ketema Belete and Tamado Tana (2018). Effect of Blended NPS Fertilizer Supplemented with Nitrogen on Yield Components and Yield of Bread Wheat (Triticum aestivum L.) Journal of Natural Sciences Research, Vol.8, No.11,2018.

Tilahun Abera and Tamado Tana (2019). Growth, yield component and yield response of durum wheat (Triticum turgidum L. var. Durum) to blended NPS fertilizer supplemented with N rates at Arsi Negelle, Central Ethiopia. African Journal of Plant ScienceVol. 13(1): 9-20.

Tilahun Geleto, Tanner, Tekalign Mamo and Getinet Gebeyehu (1996). Response of rainfed bread and durum 
wheat to source, level and timing of nitrogen fertilizer at two Vertisol sites in Ethiopia. pp 128 - 132.

Tsegaye Girma Abebe Hegano and Shimeles Tesema (2018.Bread Wheat (Triticum aestivum) Response for Blended (Micro-nutrient Containing) Fertilizer Application in Debub Ari Woreda of South Omo, Southern Ethiopia. Journal of Biology, Agriculture and Healthcare, Vol.8, No.5, 2018.

Yehuala Alemneh, Tsadiku Bamud(2019). Evaluation of Different Blended Fertilizers Types and Rates for Better Production of Wheat at Angecha Woreda. Plant. Vol. 7, No. 2, 2019, pp. 21-24. doi: 10.11648/j.plant.20190702.12

Zhang, J.H., Chung, T.D. and Oldenburg, K.R., 1999. A simple statistical parameter for use in evaluation and validation of high throughput screening assays. Journal of biomolecular screening, 4(2), pp.67-73. 